\title{
CHAPTER 112
}

\section{MATHFMATICAL MODEL OF MIXING IN NEW HAVEN HARBOR}

\author{
by
}

Michael D. Diskol

Robert A. Norr1s

Francis C. Lutzl

\begin{abstract}
A mathematical model of New Haven Harbor, a shallow embayment with approximately 8 square nautical miles of water surface within boundaries established by Long Island sound and the mouths of the Quinniplac, West and Mill Rivers, has been developed. The Harbor has extensive tidal flats and dredged channels which help to produce large lateral variations of velocity and mixing over a tidal cycle.

In order to adequately consider these lateral varlations, a two-dimensional model of mixing, dispersion, pollutant reactions, and reaeration is made by linking toqether 28 segments of the Harbor, using a series of mass-balance equations. Mixing, or dispersion, is a complex function of reversing tidal currents, salinity-induced circulation patterns, fresh-water inflow, and the physical boundaries of the Harbor. Field measurements of salinity, dissolved oxygen, $B O D$, and tidal and hydraulic factors are used, in conjunction with laboratory studies, to evaluate coefficients and rate constants for the model. The linked system of equations is solved by matrix inversion procedures on a large computer.
\end{abstract}

After verification, the model was used to predict the effect of treatment levels, outfall locations, and hydrologic parameters on oxygen levels and water quality in the Harbor. An important aspect of the work is that it presents a rational evaluation of estuarine water quality as a function of tidal mixing, outfall location, and the degree of BOD removal by proposed treatment plants, rather than the acceptance of arbitrary treatment standards.

\section{INTRODUCTION}

A critical problem confronting engineers and scientists working In the field of water-quality control is the evaluation of the required degree of treatment necessary for waste effluent discharges into river or estuarine waters. Some typical sources of

1 Consulting Engineers, M. Disko Associates, West Orange, N. J.

2 Associate, Quirk, Lawler \& Matusky Engineers, NYC 
waste effluents are industrial and domestıc discharges, perıodıc purgings of accumulated solids from combined storm and sanitary sewerage systems, surface runoff contalning quantities of nutrients and pesticides, and seepage from sanltary landfill operations in marshlands.

Each recelving water body has the capacity to assimilate a certain cuantity of introduced waste materials as a direct result of naturally occurring physical, chemical, and blological Interactions and conversion processes. Evaluation of the assimilation capacity for a particular river or estuary is a complex and difflcult task.

Typlcal methods used to determine the required degree of waste treatment necessary to malntaln oxygen levels and other water quality parameters, within the framework of the natural assimilation capacity, include field measurements and testing in the recelving water body, experimentation in verified hydraulic models, and formulation of a rational mathematical model. Each of these methods is only approximate. A number of baslc research questions still remain to be answered before any englneer or scientist can predict, with complete certalnty, the response of a recelving water body to a waste effluent discharge.

The object of this paper is to describe the formulation and use of a mathematical model to determine the relationships between the degree of waste treatment prior to effluent discharge and the resulting level of dissolved oxygen in the recelving water body which 15 New Haven Harbor. The mathematical model described, herein, is a two-dimensional system which considers pollutant variations in the lateral and longltudinal direction of the Harbor.

\begin{abstract}
Municipal sewage wastes are discharged into the Harbor from three existing primary sewage treatment plants, 1. $\theta$. the Boulevard Sewage Treatment Plant, the East street Sewage Treatment plant, and the East shore sewage Treatment plant, and from a secondary plant located in west Haven. It was desired to evaluate the degree of BOD treatment required to insure water quality standards, for a number of alternate design schemes under consideration in a sewage treatment plant modification proqram.
\end{abstract}

\title{
2. MATHEMATICAL FUNDAMENTALS FOR TWO-DIMENSIONAL MODELLING
}

Transport of any substance in an estuary is qoverned by the Law of Conservation of Mass. Figure 1 lliustrates the application of this law in a one-dimensional estuary. Waste particles discharged to an estuary are transported from the discharge polnt by convection and by dispersion. The rate of convective mass transport across any river section is equal to the product of fresh-water runoff, and the contaminant concentration.

Mixing, or dispersion, is a complex function of reversing tidal currents, salinity-1nduced circulation patterns, fresh-water inflow, and the physical boundarles of the Harbor. Dispersive 
MASS TRANSPORT RELATIONSHIPS IN A ONE-DIMENSIONAL ESTUARY

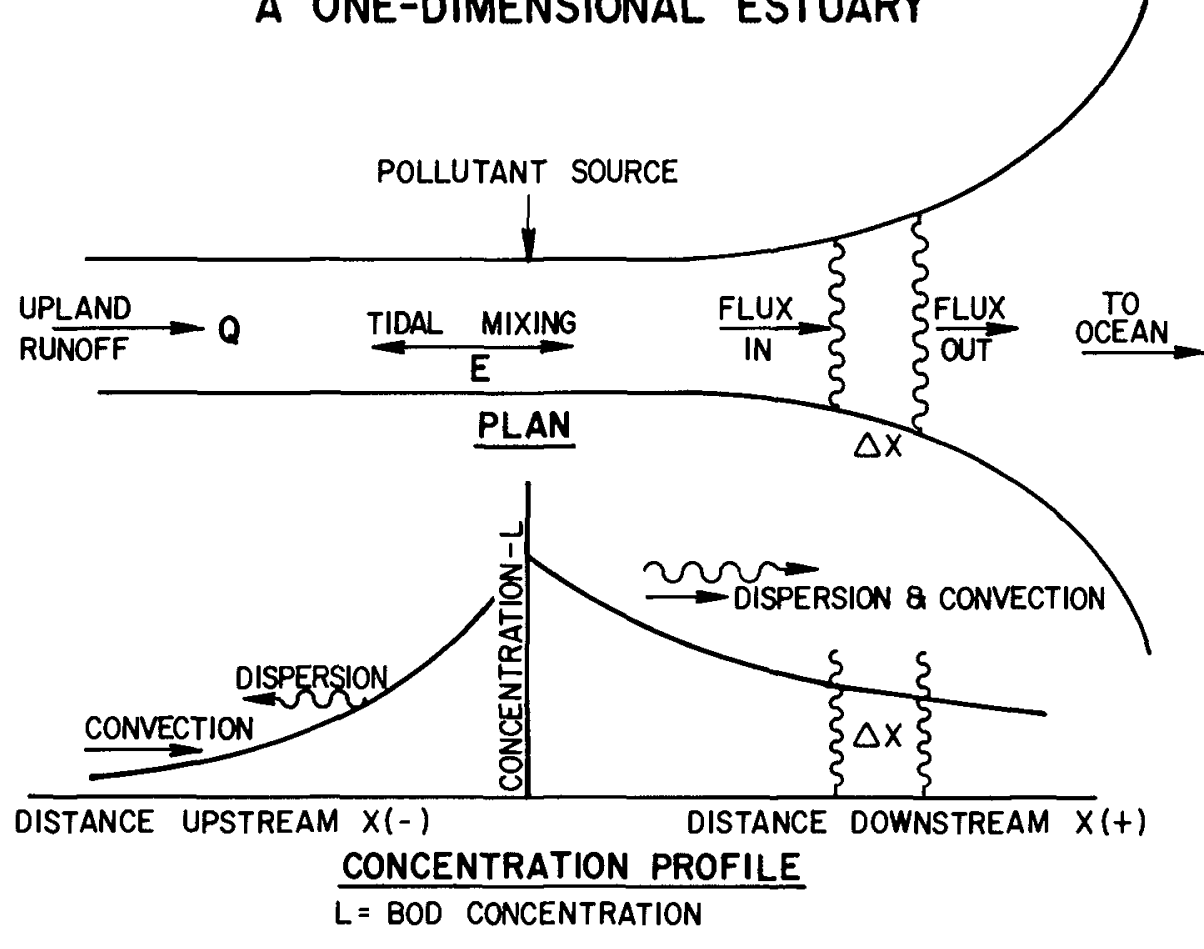

MASS BALANCE OVER VOLUME ELEMENT, A $\triangle X$

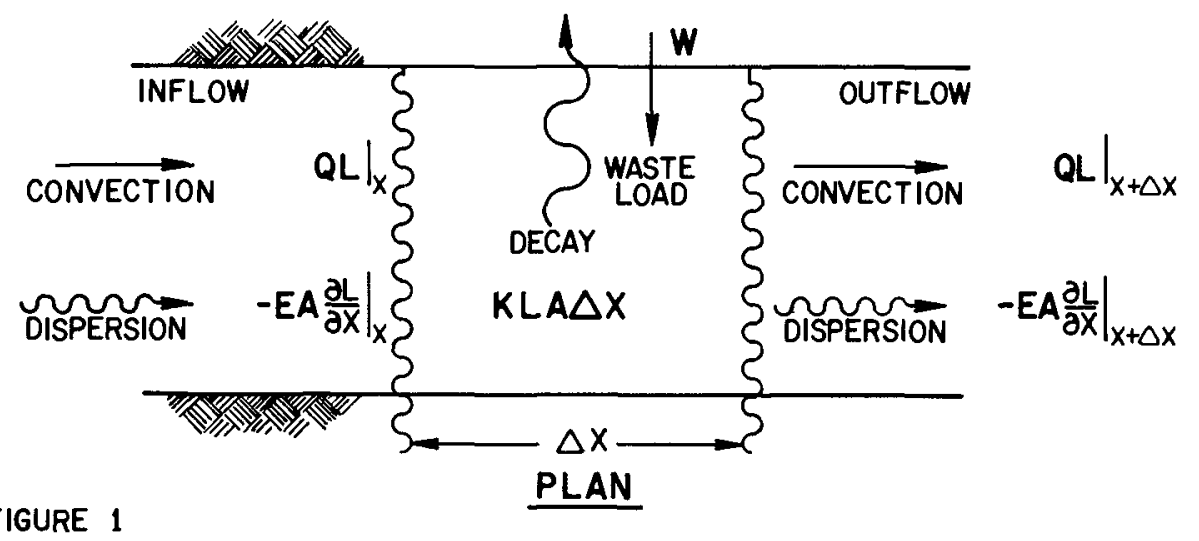

FIGURE 1 
transport occurs only in the presence of a concentration gradient of the materlal belng transported. The rate of dispersive transport is equal to the product of a dispersion coefficient, $E$, and the negative of the longltudinal concentration gradient, $\mathrm{dL} / \mathrm{dx}$. The dispersion coefficient, $E$, is a measure of the estuary's ability to transport material in the direction of a concentration gradient, regardless of the direction of net water movement.

The biochemical oxygen demand, BOD, is a measure of the oxygen required to reduce waste products by blochemlcal oxidation. The rate of $B O D$ decay is equal to the product of the first order decay constant, the $B O D$, and the volume within which the reactions are occurring.

For the case of an estuary with both longltudinal and lateral mixing and dispersion, linked volume segments in a mathematical model can be used to represent the physical system. In such a model, system parameters such as BOD are assumed to be approximately constant with depth. Each volume segment can be considered a regular polyhedron. The top and bottom of each polyhedron represent the water surface and harbor bottom, respectively. Figure 2 shows how each volume segment is directly linked to a number of other segments.

A mass balance over any volume segment shown in Figure 2 is written

INFLOW - OUTFLOW + PRODUCTION - LOSSES = ACCUMULATION $\ldots \ldots(1)$

For a steady-state case, the ACCUMULATION of BOD within any particular volume segment is zero, and EQUATION (1) gives

INFLOW - OUTFLOW + PRODUCTION - LOSSES $=0 \ldots \ldots \ldots \ldots \ldots$ (2)

Each of the terms are described in detail below.

The INFLOW and OUTFLOW terms are the sums of convective and dispersive transport across the faces of the volume segments. A direction 19 assigned for convective and dispersive transport, and, using this sign convention, a consistent material balance is developed for each linked segment. The convectlve components are the product of each flowrate, $O$, and each respective BOD concentration, L. The dispersive component is the term, EA(dL/dS), where $E$ is the average dispersion coefficlent at the interface of each segment linkage, $A$ is the interfacial area, and $S$ is a distance in the direction normal to the area, $A$.

The PRODUCTION of BOD in a volume segment represents the sum of the inputs of waste effluents, surface runoff, and additions of BOD from the scour, by currents, of bottom deposits in the benthal layer of partly decomposed organic products. The net PRODUCTION 1s, therefore, estimated as a BOD load of $W$ pounds per day. 
TWO-DIMENSIONAL MSSS TRANSPORT RELATIONSHIPS

- seuiment midooint \.

-..- HAFBOR BOUNDARY

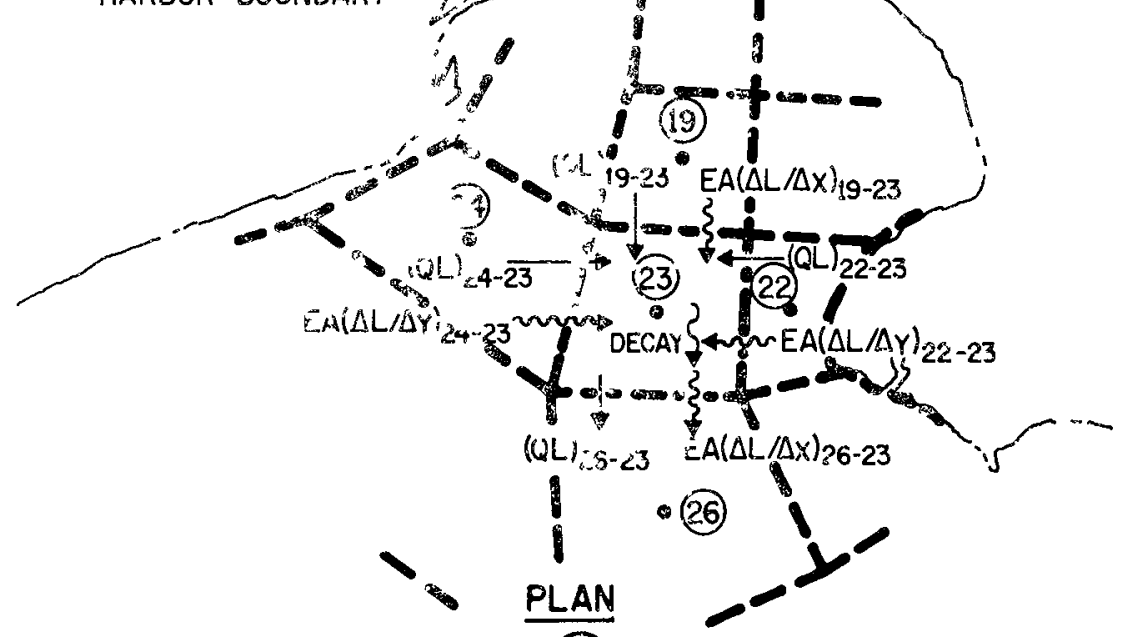

LINKAGE BETWEEN SEGMENT (23) AND ADJOINING SEGMENTS

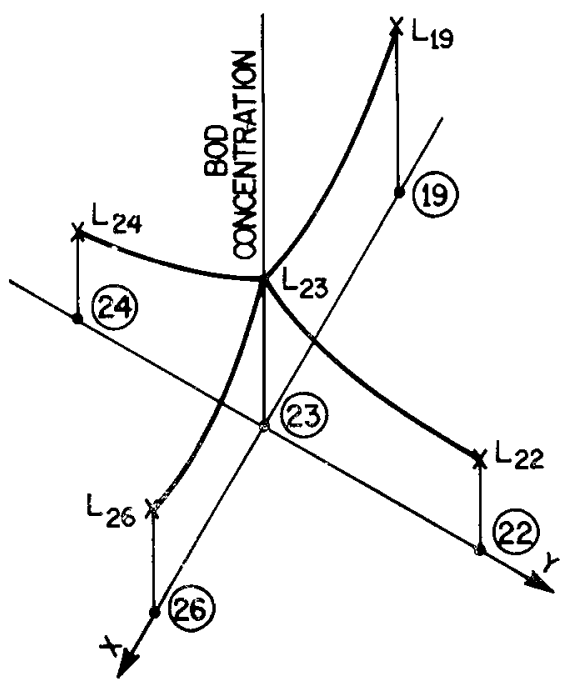

BOU CONCENTRATIONS IN ADJACENT SEGMENTS

FIGURE 2 
The LOSSES of $B O D$ in a segment would include the removal of $B O D$ by sedimentation or absorption, and decay. The BOD reduction, by sedimentation or absorption, may be assumed proportional to the amount of insoluble BOD in the water. The decay of BOD is assumed to be a first-order reaction, proportional to the concentration of BOD. The net decay of BOD in any segment is given by $K_{r} L V$, where $K_{r}$ is the composite BOD decay coefficient (to the base e) due to decay and sedimentation, $L$ is the average BOD concentration in the segment, and $V$ represents the segment volume.

In New Haven Harbor, losses of BOD due to sedimentation and absorption were small because of the high tidal flushing rate. If, however, these effects were substantial in any particular volume segment representing a portion of the Harbor, allowance could be made to reflect these parameters in the coefficients of that segment's mass balance equation.

An algebralc substitution of the individual contributions into Equation 2, for each volume segment, gives

$$
\Sigma O L-\Sigma E A(d L / d S)+W-K_{r} L V=0 \ldots \ldots \ldots \ldots \ldots \ldots
$$

Equations for each segment are developed and linked, noting the relative interconnection, the advective and dispersive transport conventions assumed, and appropriate coefficients such as $\mathrm{K}, \mathrm{E}$, and $\mathrm{A}$.

Dissolved oxygen concentration is used as a principal index of organic waste pollution in a waterway. As the level of Do concentration is decreased, the capacity of a waterway to assimilate waste discharges is reduced, requiring upgrading of treatment facilities for waste flows. The important source of replenishment of DO is atmospheric oxygen transferred to the waterway in proportion to the currents and other estuarine parameters.

Application of Equation 2 to oxygen transport follows the approach outlined above for $B O D$ and yields an equation analogous to Equation 3. The INFLOW and OUTFLOW terms are similar to the BOD terms. The convective term is the product of $O$ and $D$, the dissolved oxygen deficit or the difference between oxygen saturation and actual oxygen concentration in the water. The dispersive term is the product, EA(dD/dS).

The PRODUCTION of DO in a volume segment is the external input of oxygen reaeration from the atmosphere through the water surface, and the addition of oxygen by photosynthesis. The mechanism of reaeration is represented by $K_{A} D V$, where $K_{A}$ is the coefficient of oxygen transfer from the atmosphere 1ntô the seament. $\mathrm{K}_{\mathrm{A}}{ }^{\mathrm{A}}$, of course, a parameter that varies as a function of water depth and current velocity in various sections of the Harbor.

The LOSSES of DO in a volume segment would include the removal of oxygen from the water by diffusion into the benthal layer to 
satisfy the oxygen demand in the aerobic zone, by the purging action of gases rising from the benthal deposits, and by the respiration of plankton, diatoms, and other life. The rate of removal of oxygen, or deoxygenation, is represented as $\mathrm{KLV}$, where $\mathrm{K}$ is the coefficient of deoxygenation or rate of loss of oxygen associated with satisfying the BOD.

The production of oxygen by photosynthesis, the removal of oxygen by respiration and benthic effects were al1 judged to be minor effects that tended to balance one another in New Haven Harbor over long-term periods.

An algebralc substitution of the individual contributions into Equation 2, for each volume segment, gives

$$
\Sigma Q D-\Sigma E A(d D / d S)-K_{A} D V+K L V=0 \ldots \ldots \ldots \ldots \ldots
$$

The mass balance technique employed to develop Equations 3 and 4 is used to formulate a series of equations for BOD and dissolved oxygen deficit, $D$, in each segment. After solution of these equations, the corresponding DO in each segment is then obtained by subtraction of the dissolved oxygen deficit, $D$, from the saturation oxygen concentration.

\section{GENERAL DESCRIPTION OF NEW HAVEN HARBOR}

New Haven Harbor is a shallow embayment with approximately 8 square nautical miles of water surface within boundarles established by the Long Island Sound breakwaters and the mouths of the Quinniplac, West, and Mlll Rivers. The Harbor width varies from less than a thousand feet just downstream of the juncture of the Mill and Quinniplac Rivers to approximately two miles at its mouth. Extensive tidal flats exist on the west shoreline of the Harbor, while the east shore is generally irregular.

The existence of extensive areas of tidal flats, variable harbor width, shore irreqularities, deep navigational channels, breakwaters, and localized fresh-water inflows in a tidal waterway, all require that the mathematical modelling consider both lateral and longltudinal directions. The generally accepted one-dimensional estuarine model leaves lateral mixing effects unaccountable. such a scheme would be forced to employ a cross-sectional average velocity in its development, and would result in potentially substantial errors in contaminant concentration predictions.

The mean depth of the Harbor below mean low water is about 11.5 ft. The mean tidal range for the Harbor is about $6.2 \mathrm{ft}$. The tidal prism, which is the mean volume of water that is exchanged from the Harbor between mean high and mean low water, 1 s approximately $1.87 \times 10^{9}$ ft. ${ }^{3}$. The volume of the Harbor is about $4.4 \times 10^{9} \mathrm{ft}^{3}$ at mean water level. The ratio of the tidal prism to the mean volume of the Harbor is a measure of the flushing that occurs. It should be noted that this exchange occurs twice a day, since the period of the tide is about 12.4 hours. The 
total tidal flushing is equivalent to the replacement of 848 of the Harbor volume each day.

The large variation in Harbor width controls the relative magnitudes of fresh-water and ocean-water velocities. The shore irregularitıes, breakwaters, and the deep navigational channels produce localized currents. Current data was obtaıned from "A Hydrographlc Survey of New Haven Harbor, 1962-1963", by Alyn Crandall Duxbury of the Bingham Oceanographic Laboratory of Yale Unlversity. The survey is published as connectlcut water Resources Bulletin No. 3A.

Shellfish breeding areas are malntalned within the breakwaters, and extensive shellfish harvesting grounds are malntalned beyond the breakwaters. In addition, portions of the Harbor are also reserved for recreational purposes. Bathing beaches line both the east and west shores at the Harbor entrance.

\section{APPIICATION OF MODELLING TECHNIQUES TO NEW HAVEN HARBOR}

In order to apply the material balance approach described in the previous section of this report, the Harbor was divided into 28 volume segments as shown in Figure 3. Segments 1 through 5 are associated with the oulnniplac River, segment 6 with the Mill Rlver and segments 13 and 14 with the West Rlver.

Segmentation was made on the basis of current and depth patterns. Current patterns were determined from composite Bingham Oceanographic Laboratory hydrographic measurements of ebb and flood tide conditions. Depth patterns were obtained by constructing over 60 profile sections of the Harbor.

Each segment was linked to the adjolning segments by applying the material balance, defined by Equations 3 and 4 , for BOD and Do conditions. Many of the segments are linked to four other segments. Evaluation of Equations 3 and 4 often required consideration of ten or more separate coefficients for each segment.

The model could have been divided into a larger number of segments if comprehensive field surveys and measurements were avallable to justify the additional complexity involved. The amount of total complexity increases as an exponential function when the number of segments increases. Division of the Harbor into 28 segments was judged to be the optimum segmentation for the avallable field data on DO, currents, BOD, etc.

Evaluation of the many parameters required for Equations 3 and 4 was a time-consuming process. The following parameters had to be computed for each segment: the BOD load per unit of time; cross-sectional areas at each boundary; fresh-water flow into and out of each segment; volume of waste effluent into each segment; the decay rate of $B O D$; the oxygen saturation concentration; the oxygen transfer from the atmosphere to water, the prevalling currents, and the mean water volumes. 


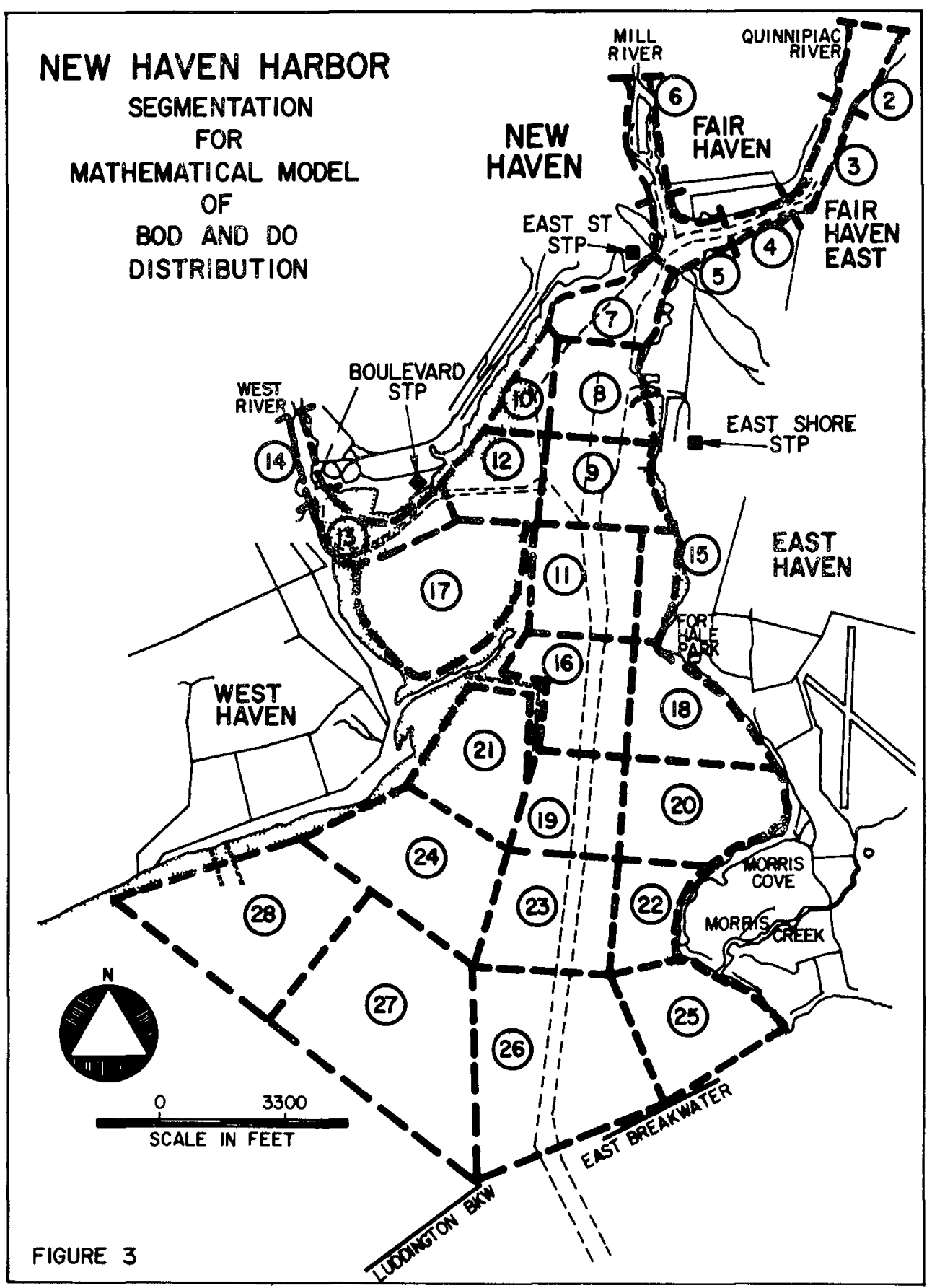


Information required for cross-sectional areas, segment volumes, depths, and tidal range were obtalned from U. S. Geologlcal Survey maps, U. S. Coast and Geodetıc Survey maps, and other published Harbor data.

Fresh-water flowrates for the oulnnlplac Rlver Basin at Wallingford, Connectlcut were obtalned from Geologlcal survey records. Flowrates for the Mlll Rlver and the West River were estimated from a study of watershed areas, and watershed characteristics. Critical flowrates from all three rivers into the Harbor were computed.

Tidal currents were obtalned from composite Blngham survey measurements for ebb and flood condltions. Average current values were computed, based on tidal cycle relationships and the ebb and flood value.

The longltudinal dispersion coefficient at each segment boundary was computed from a knowledge of tidal currents, fresh-water flow, and salinity measurements obtalned by the BIngham hydrographic survey. Longltudinal dispersion can be directly computed from the mean salinlty concentration, the salinlty gradients, and the average current at the segment boundary. In several non-critical areas of the Harbor, Blngham velocity data was not avallable. In these cases, the longltudinal dispersion coefflclents were estlmated from a study of the overall patterns of the computed longltudinal dispersion coefficients and the measured currents in the Harbor.

The first-order, BOD decay rates, or coefflclents, were determined from a laboratory analysis of Harbor water samples. Seven representative water samples were obtalned from predetermined Harbor locations on April 9, 1969. Long-term BOD evaluations were performed to determine the present $K_{r}$ decay coefficient of Harbor waters. The $\mathrm{K}_{\mathrm{r}}$ rate was determined to be about $0.31 / \mathrm{day}$. This measured value is normal for primary effluent and was used for model verification and to estimate the future decay rates of secondary effluent. All seven samples showed $k_{r}$ rates that were similar. An estimated decay rate of 0.20 /day was used for the 1990 secondary effluent.

The coefficlent of atmospheric reaeration, $K_{A}$, was computed, using the well-known $O^{\prime C}$ Connor-Dobbins formula, and another equation developed by U. S. Geologlcal Survey personnel. Atmospherlc reaeration in streams is a function of velocity and depth. The expressions developed for streams are commonly adopted for estuarıne reaeration.

Application of the mass balance approach to each segment, including all the above computed parameters, results in 28 equations for $B O D$ and another 28 equations for the dissolved oxygen deficlt, D. A system of equations, based on Fquations 3 and 4 , can be written in terms of the midpoint concentrations, in the following form 


$$
\begin{gathered}
a_{1-1} L_{1}+a_{1-2} L_{2}+\ldots+a_{1-28} L_{28}=w_{1} \\
\vdots \\
a_{28-1} I_{1}+a_{28-2} L_{2}+\ldots+a_{28-28} L_{28}=w_{28} \ldots \ldots \ldots \ldots
\end{gathered}
$$

and

$$
\begin{gathered}
\mathrm{b}_{1-1} \mathrm{D}_{1}+\mathrm{b}_{1-2} \mathrm{D}_{2}+\ldots+\mathrm{b}_{1-28} \mathrm{D}_{28}=\mathrm{C}_{1} \mathrm{~L}_{1} \\
\vdots \\
\mathrm{b}_{28-1} \mathrm{D}_{1}+\mathrm{b}_{28-2} \mathrm{D}_{2}+\ldots+\mathrm{b}_{28-28} \mathrm{D}_{28}=\mathrm{C}_{28} \mathrm{~L}_{28} \ldots \ldots \ldots
\end{gathered}
$$

In the above system of equations, the $a$ and $b$ coefficlents are obtalned by summation of all the terms pertaining to a respective subscripted $L$ or $D$ parameter. The $C$ coefficients are equivalent to the respective segment values of $\mathrm{KV}$. Many of the $a$ and $b$ coefficients have zero values.

Equations 5 and 6 are sets of simultaneous linear algebralc equations with unique solutions, which are readily solved by any number of standard numerical techniques. of those avallable, matrix inversion was chosen because of its ease of application, and directness for the system studied.

Using matrix algebra, the BOD waste loads into each segment become a column matrix. This column matrix is equated to a coefficient matrix which has 28 rows and 28 columns, and a column matrix which consists of the unknown BOD concentrations in each model segment. Each element of the 28 by 28 coefficient matrix is computed from the varlous parameters described above.

The coefficient matrix is inverted using standard numerical techniques on a computer. After matrix multiplication of the inverted coefficient matrix and the waste load column matrix, the unknown BOD concentration column matrix can be computed. A similar procedure is performed on the 28 equations for D. However, the computed BOD concentrations are required in order to solve the $D$ equations.

The solution of the BOD and oxygen deficit system, Equations 5 and 6, was programmed in FORTRAN $V$ for processing by a UNIVAC 1108 computer. One main program was constructed with a subroutine for matrix inversion. The program can be converted to most FORTRAN IV systems with few changes. An overall flowchart of the program is shown in Figure 4. 


\section{FLOW CHART FOR COMPUTER PROGRAMMING}

READ IN HARBOR PARAMETESTS, TERAP, OXYGEN SATURATION, FLOW S BOD INPUTS

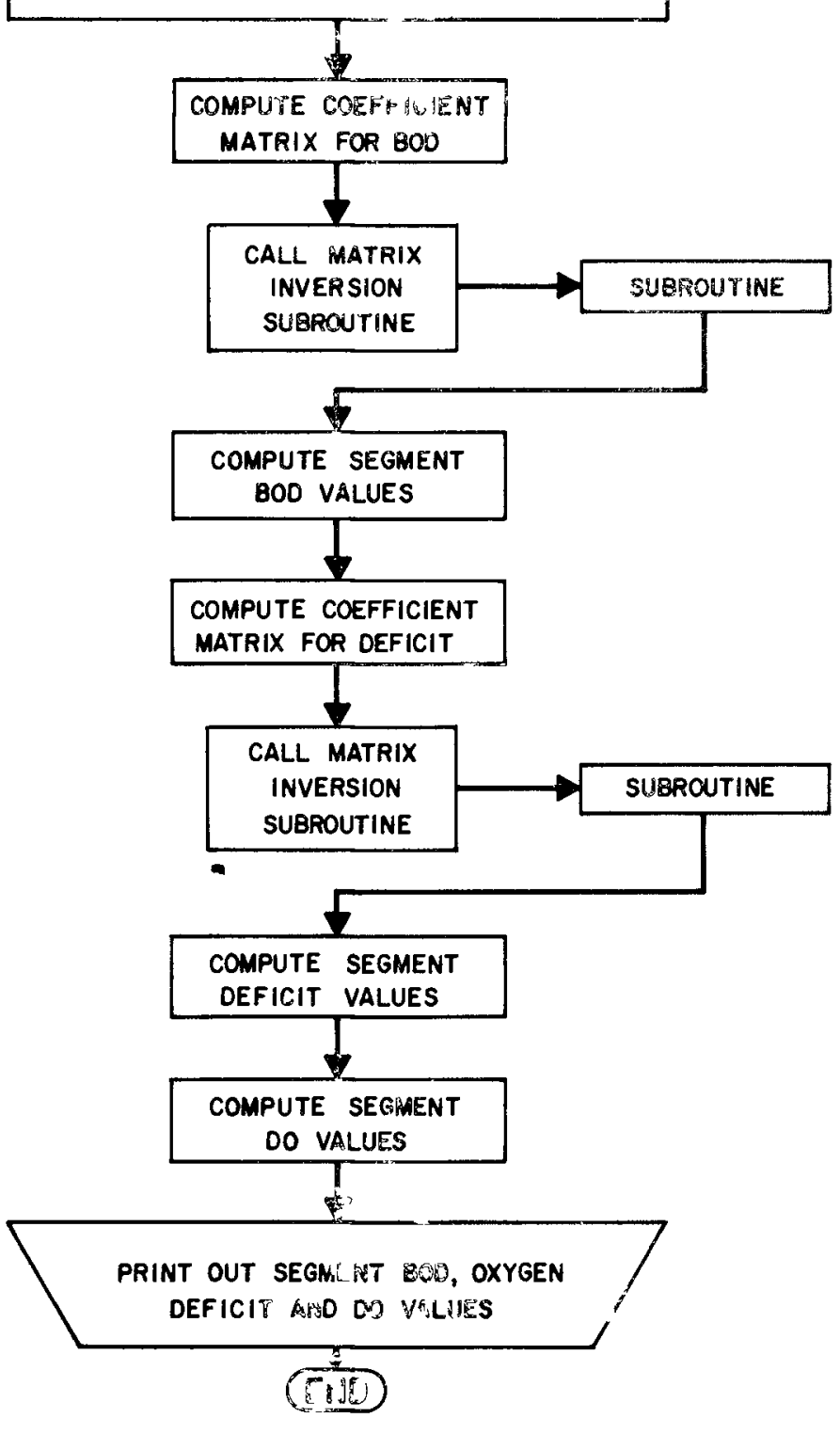

FIGURE 4 
The computer program and mathematical nosel can be adopted sid modified to compute colıform patterns, raduoactivity distrıbu= tions, temperature distributions, and contaminant patterns resulting from various input loadings. program and model modifications would require additional field measurements for the particular type of parameter simulated.

\section{MODEL VERIFICATION IN NEW HAVEN HARBOR}

Model verlfication is accomplished by comparing predicted DO concentrations to measured Do concentrations. Measurements of Do in the Harbor are limited. The only survey giving a reasonable representation of the DO patterns of the Harbor was performed by the Bingham oceanographlc Laboratory from october 1962 through september 1963. In this survey, DO measurements were made approximately once a week, at nine stations in the Harbor and at three depths at each station.

The Do measurements showed significant varlation, depending on the tidal phase of the survey and the cumulative rainfall for the perlod immediately prior to the survey date. The mathematical model, whlch was developed for steady-state conditions, is not applicable to measurements of a duration less than a full tidal cycle. Thus, for valid comparisons of model values to fleld data, predicted DO concentrations must be compared to measured DO concentrations that represent the average Do for a complete tidal cycle. Since numerous measurements within a tidal cycle are not avallable, the exact tidal cycle average Do must be estımated.

Absolute verlfication of the mathematical model requires complete and up-to-date fleld surveys to measure prescribed parameters. These types of field surveys must be designed with the mathematical model in mind so that the data obtalned may be optimally employed. To accomplish this goal, the data must be collected at specific times and locations as predescribed by the model.

Model analysis indicated that the model Do predictions were relatively insensitive to local varlations in $E, K_{r}$, and $Q$ when compared to lts sensitivity to varlations in waste loads. Changes in waste loads are directly related to changes in DO. Consequently, model verlfication depends upon accurate determination of the waste loads that constituted an input to the Harbor colncldent with the survey selected for verification purposes. All surveys that followed periods of excessive rainfall would be unsultable for verification purposes because the actual waste loads during these perlods are unknown. During the Bingham hydrographlc surveys, the waste loads from the existing sewage treatment plants were determined from flow and BOD measurements made on the effluents.

Industrlal waste loads were computed based on discharge flow estimates as reported to the Water Resources Commission by each industry. BOD measurements of the dlscharge flows were avallable for the largest flows. Where measurements were not avallable, reasonable estımates were used. 
The following waste loads were estimated for dry weather conditions during the Bingham hydrographic surveys of 1962-1963:

\begin{tabular}{lr}
\multicolumn{1}{c}{ Source } & Load. Lb. BOD ${ }_{5} /$ Day \\
\cline { 2 - 2 } Boulevard STP & 13,900 \\
East Street STP & 14,500 \\
East Shore STP & 3,940 \\
West Haven STP & 9,900 \\
Central Business District & 6,550 \\
(temporary during this period) & 3,800 \\
Industrles & Total
\end{tabular}

The Bingham survey of April 17, 1963 can be selected to 1llustrate the problems involved in verification of the model. For a six-day period prior to April 17, 1963, the cumulative rainfall was 0.07 inches.

Measurements of oxygen were made on a rising tide. The hydrographlc survey started at the breakwaters in the outer Harbor and proceeded inward to the Quinnlplac River. Bingham station OH2 is recorded as sampled within 2 hours after low water slack. Bingham stations $\mathrm{MC} 3, \mathrm{MCl}, \mathrm{FH} 2, \mathrm{OP} 3, \mathrm{OP} 2$, and $\mathrm{OP} 1$ were sampled within one hour of mean tidal stage. Stations $\mathrm{Hl}$ and $\mathrm{Ql}$ were sampled within one hour after mean tidal stage. In general, surveys will show a lower value of DO at low water conditions, and a higher Do at high water.

Measurements from several of the nine stations are not sultable for direct comparison to the model output. Analysis of measured data at a station showed considerable variations in oxygen concentrations, temperatures, and salinities for the three grab samples taken at the surface, 10-foot and 20-foot depths. The following listing shows a comparison between April 17, 1963 survey estimates of oxygen concentrations and model predictions at several stations:

\begin{tabular}{|c|c|c|}
\hline $\begin{array}{l}\text { Blngham } \\
\text { Survey } \\
\text { Station }\end{array}$ & $\begin{array}{c}\text { Range of Oxygen } \\
\text { Deflcit from } \\
\text { Survey Data } \\
\end{array}$ & $\begin{array}{c}\text { Oxygen Deficit } \\
\text { from Model } \\
\end{array}$ \\
\hline & (ppm) & (ppm) \\
\hline $\begin{array}{l}\text { OP1 } \\
\text { OP2 } \\
\text { OP3 } \\
\text { FH2 } \\
\text { MC1 } \\
\text { OH2 }\end{array}$ & $\begin{array}{l}1.1-0.8 \\
0.8 \\
1.1-0.8 \\
0.4-0.1 \\
1.1-0.6 \\
0.7-0.6\end{array}$ & $\begin{array}{l}0.9 \\
0.9 \\
0.9 \\
0.8 \\
0.6 \\
0.5\end{array}$ \\
\hline
\end{tabular}


In general, the model output closely matches the oxygen deficits measured in the hydrographlc survey. Stations OPI, OP 3 , and OH 2 are within $0.2 \mathrm{ppm}$. Other stations are within the survey range or relatively close to 1 t.

\section{USE OF THE VERIFIED MATHEMATICAL MODEL FOR WATER QUALITY PREDICTION}

The mathematical model of New Haven Harbor was used to predict the effect of the degree of BOD removal during effluent treatment on the dissolved oxygen concentration in the waters, and also to evaluate the water quality resulting from the use of long outfalls to discharge waste effluent into deeper sections of the Harbor with higher mixing characteristics. The estimates of future waste loads, during the maximum month in 1990, were used for model predictions.

The major waste contributions to the Harbor are discharged from the Boulevard, East street, East shore, and West Haven Sewage Treatment plants. Additional waste sources are direct industrial. dlscharges and overflows from the munlclpal sewage system.

At present, more than two-thirds of the tributary drainage areas of the Boulevard, East street, East Shore, and West Haven sewage Treatment plants are served by a combined sewer system. consequently, sewage that settles and forms deposits in sewers during dry periods is flushed from the system during significant rainfalls, resulting in an instantaneous load several times larger than the normal BOD discharge. These irregular, instantaneous loads are a direct cause of the low Do condltions that sometimes occur. Future plans for New Haven include modifying the present combined system into a completely separate system.

The following is a list of the 5-day BOD loads for the maxlmum month in 1990

$\begin{array}{lc}\text { Sewage Treatment Plant } & \text { Load, Lb. BOD } 5 / \text { Day } \\ \text { Boulevard } & 52,500 \\ \text { East Street } & 63,500 \\ \text { East Shore } & 64,000 \\ \text { West Haven } & 37,500 \\ & \frac{217,500}{}\end{array}$

The Boulevard, East street, and East shore operations are older, primary treatment plants. The West Haven operation is a secondary treatment plant.

Since the primary treatment plants were under conslderation for renovation, the model was used to evaluate whether any substantial water quality benefit could result from combining the flow in one or more larger, rebullt operations. Five alternate treat- 
ment schemes were proposed as follows

\begin{tabular}{|c|c|c|c|}
\hline \multirow[b]{2}{*}{ Scheme } & $\mathrm{BOD}_{5} \underset{1 \mathrm{nto}}{1 \mathrm{~b} / \mathrm{Day}}$ & $\mathrm{BOD}_{5} \underset{\text { 1nto }}{1 \mathrm{~b} / \mathrm{Day}}$ & $\mathrm{BOD}_{5} \underset{1 \mathrm{nto}}{1 \mathrm{~b} / \mathrm{Day}}$ \\
\hline & Boulevard site & East st site & East Shore site \\
\hline 1 & 52,500 & 63,500 & 64,000 \\
\hline 2 & $\begin{array}{r}52,500 \\
63,500 \\
116,000\end{array}$ & - & 64,000 \\
\hline 3 & 52,500 & - & $\begin{array}{r}63,500 \\
64,000 \\
127,500\end{array}$ \\
\hline 4 & -- & $\begin{array}{r}52,500 \\
63,500 \\
16,000\end{array}$ & 64,000 \\
\hline 5 & - & -- & $\begin{array}{r}64,000 \\
63,500 \\
52,500 \\
180,000\end{array}$ \\
\hline
\end{tabular}

The estumated average monthly BOD loads for 1990 are about elghty percent of the maximum monthly loads above. The west Haven secondary treatment plant wlll, under all schemes, discharge 37,500 lbs. of 5 -day BOD per day

One positive result that the computer model showed was that no particular alternate scheme offered significant advantages over the others in terms of average BOD and DO levels resulting in the Harbor The basic reason for the essentialiy similar water quality patterns produced by the 5 schemes was that the Boulevard, East Street and East Shore plants are all located in the inner section of the Harbor within a distance of 8,000 feet from each other. Hence, the high degree of tidal flushing that occurs effectively spreads and mixes the BOD waste loads throughout the inner Harbor, whth sumilar dissolved oxygen concentration patterns resulting.

The conclusion drawn from these computer model results is that selection of an alternate scheme, at a given BOD removal rate, should be governed by the economics of construction and operation of the rebullt plant or plants in terms of the resulting water quality, and protection of the beach areas, outputs from all the schemes are essentially equal This conclusion 1 s predicted on the condition that discharge at or near the shoreline will be into tidal waters and will not be allowed to spill onto tidal mud flats where BOD concentrations can bulld up.

In order to evaluate the relationship between the degree of effluent treatment and resulting dissolved oxygen in the Harbor, 
a series of computer runs was made for each of the 5 alternate schemes at BOD removal rates of $258,50 \%, 758,858$, and $90 \%$. Printout 1 shows typical BOD output. Table l lists a typical result for the minimum dissolved oxygen in the Harbor, versus the percent of BOD removal.

The type of output displayed in the above Printout and Table 1 is an example of the type of rational englneering analysis that can be obtalned from a predictive mathematical model. Instead of designing a waste treatment operation to an arbitrary set of $B O D$ removal standards or effluent concentration levels, a verified mathematical model can be constructed to determine the relationship between the degree of BOD removal and the approximate distribution of dissolved oxygen, longltudinally and laterally, in the receiving waterbody. For example, if a minimum tidal average of 6 ppm of dissoived oxygen was desired in the Harbor, approximately 85 \% BOD removal would be required for the projected effluent discharges.

TABLE 1

EFFECT OF DEGREE OF BOD REMOVAL ON MINIMUM DISSOLVED OXYGEN IN NEW HAVEN HARBOR

$\&$ BOD

Removal

Durıng

Treatment
TIDAL AVERAGED

NEW HAVEN HARBOR MINIMUM DO, PPM

\begin{tabular}{c} 
Scheme 1 \\
Separate Effluent \\
Discharges at \\
Boulevard, \\
East St., and \\
East Shore STP \\
\hline
\end{tabular}

Scheme 5

All Effluent Directed to East Shore STP

$\begin{array}{llr}25 & 3.8 & 4.1 \\ 50 & 4.7 & 4.9 \\ 75 & 5.6 & 5.7 \\ 85 & 6.0 & 6.0 \\ 90 & 6.1 & 6.2\end{array}$

Another important predictive feature of the verified mathematical model is the ablilty to evaluate the effect of the use of outfalls to dilute the discharged effluent and, hence, to effectively reduce the level of BOD removal required. Table 2 shows a typical summary of computer runs at various percentages of BOD removal. Inspection of the table shows that extension of the outfall into deeper water of the Harbor allows reduction of the degree of sewage treatment, but maintains the desired minimum dissolved oxygen concentration. The economic feasibility of using outfall extensions must be evaluated after detalled construction cost estimates. 


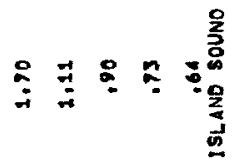

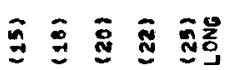
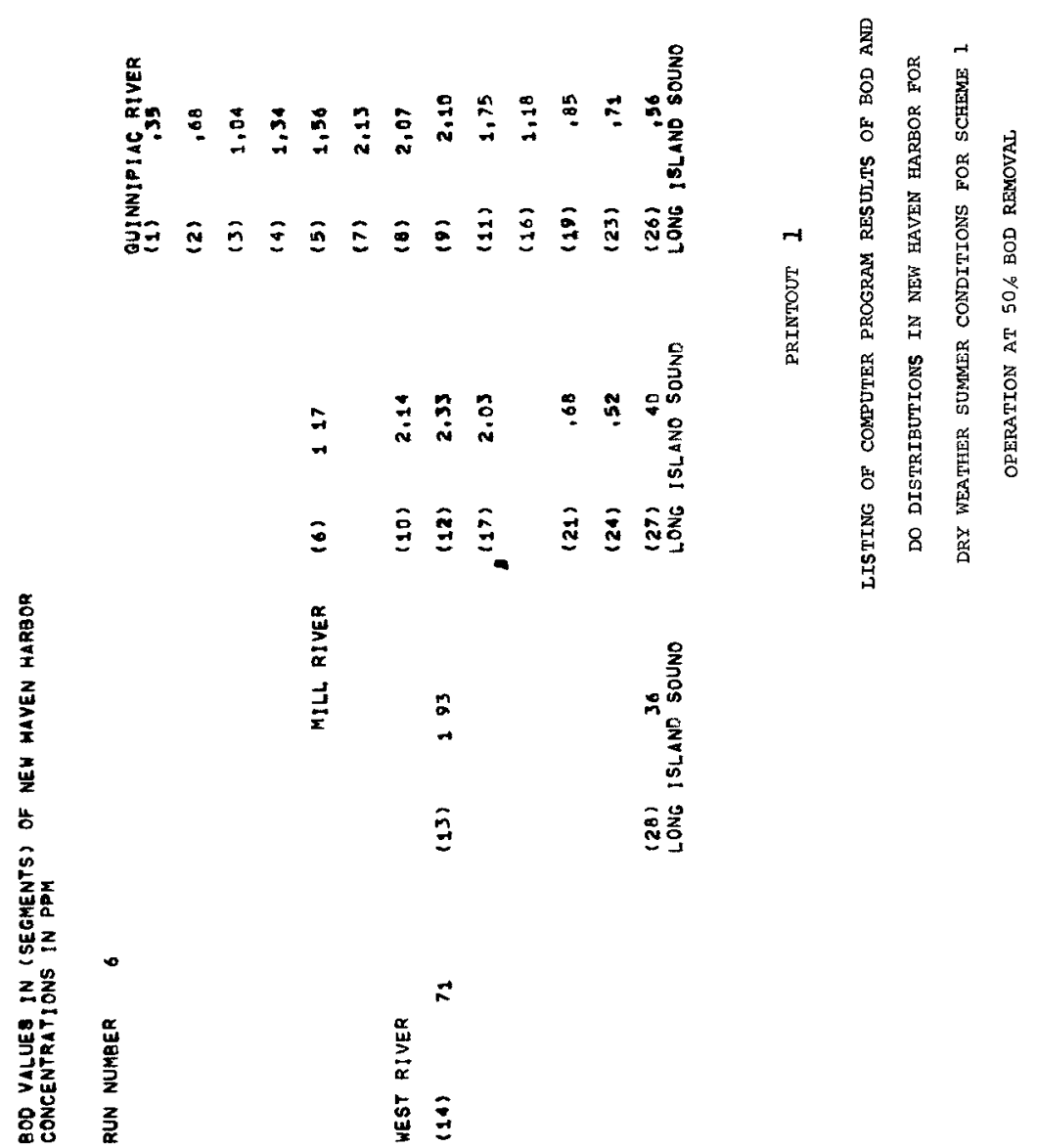


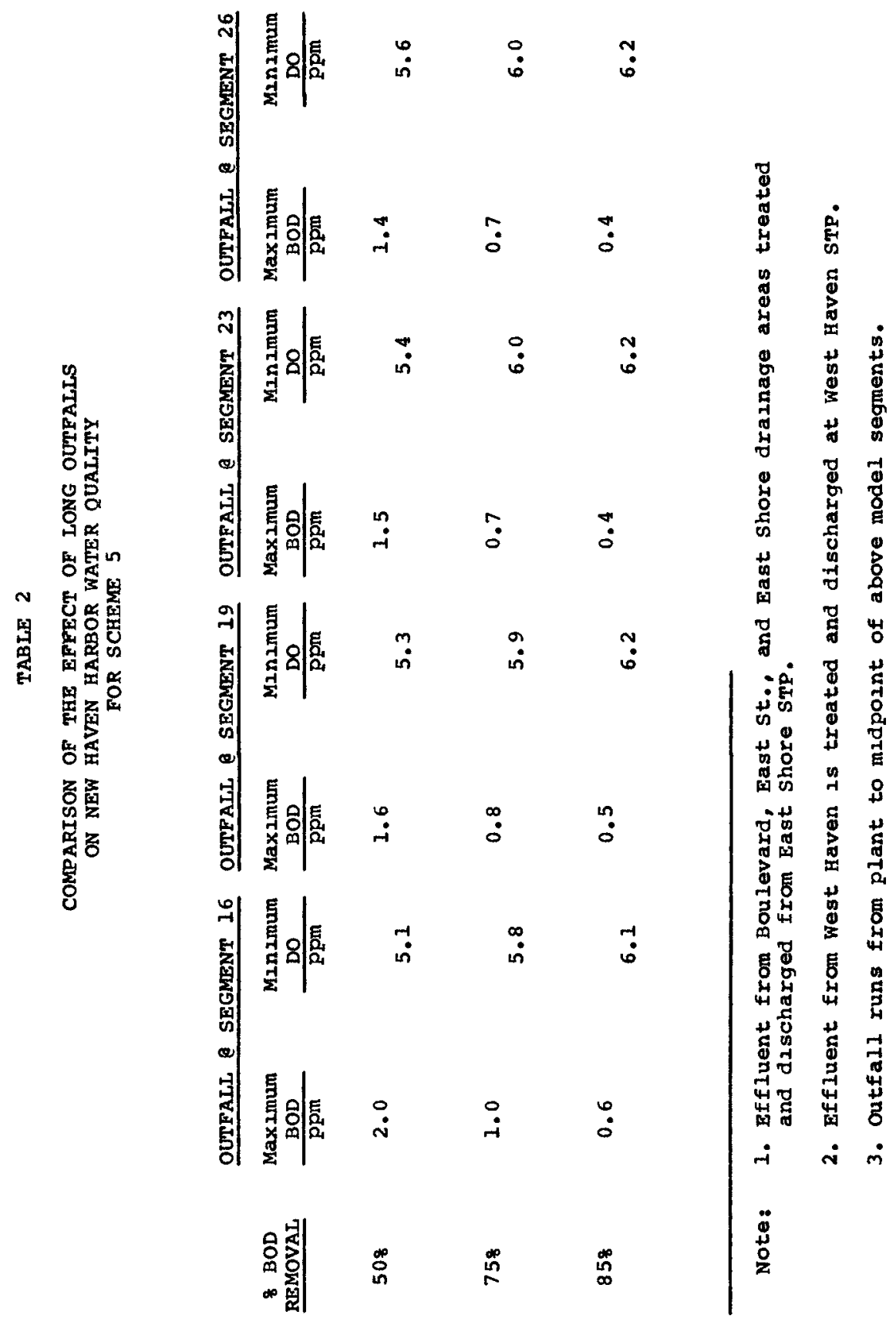




\section{ACRNOWLEDGEMENTS}

This work was performed under the sponsorship of the Water Resources Commission of the state of Connecticut, and was performed by Quirk, Lawler and Matusky Engineers, NYC. 